\title{
The CJEU's reliance on the case law of by the ECtHR since 2015: Opinion 2/13 as a game changer?
}

\author{
Jasper Krommendijk ${ }^{1}$
}

This is an unedited version. Edited version forthcoming in: E. Bribosia \& I. Rorive (eds.), A Global And Multilayered Approach Of Human Rights: Promises and Challenges

(Cambridge, Antwerp, Portland: Intersentia, 2017).

Just before Christmas 2014, the Court of Justice of the European Union (CJEU) unexpectedly put a stop to the EU's accession to the European Convention of Human Rights (ECHR). It declared the agreement on the accession of the EU to the ECHR to be incompatible with the specific characteristics and autonomy of EU law in Opinion 2/13. ${ }^{2}$ This Opinion reflects the increasing worries of the CJEU about the sometimes far-reaching case law of the European Court of Human Rights (ECtHR) which could hamper the effectiveness of EU law. ${ }^{3}$ This tension has become especially visible in the Area for Freedom Security and Justice in cases dealing with the Dublin Regulation and the European Arrest Warrant. While the CJEU has to balance the uniformity, primacy and effectiveness of EU law and the upholding of the system based on mutual trust and mutual recognition with fundamental rights concerns, the ECtHR's sole objective is to guarantee the latter. CJEU judges expressed their concern that the ECtHR does not always take the particularities of EU law, such as mutual trust in the context of the Dublin system, sufficiently into account, because some Strasbourg judges are not familiar with them. ${ }^{4}$ There has also been growing uneasiness in Luxembourg with the intrusive case law of the ECtHR in relation to the preliminary reference procedure in Article 267 TFEU. This is because the ECtHR found violations of Article 6 ECHR in Dhahbi and Schipani for the failure of the highest Italian court to provide a statement of reasons for its refusal to request a preliminary ruling from the CJEU on the basis of Article 267 TFEU. ${ }^{5}$ Similar frustration exists in Strasbourg vis-à-vis the CJEU and especially Opinion 2/13, which was not received warmly. Former President of the ECtHR, Spielmann, stated that it was 'a great

\footnotetext{
${ }^{1}$ I would like to thank Leonie Huijbers, Tobias Lock and Bruno de Witte for their valuable comments on earlier versions of this chapter.

${ }^{2}$ Opinion 2/13, ECLI:EU:C:2014:2454.

3 T LOCK, 'The future of the European Union's accession to the European Convention on Human Rights after Opinion 2/13: is it still possible and is it still desirable?' (2015) 2 European Constitutional Law Review 239, 259; X GROUSSOT, J HETTNE and G T PETURSSON, 'General principles and the many faces of coherence: Between law and ideology in the European Union', in: Studies of the Oxford Institute of European and Comparative Law, Hart 2016.

${ }^{4}$ Interviews as discussed in J KROMMENDIJK, 'The use of ECtHR case law by the Court of Justice after Lisbon: the view of Luxembourg Insiders' (2015) 6 Maastricht Journal of European and Comparative Law 812, 831. The ECtHR has, however, recently held in Avotinš that it is 'mindful of the importance' of mutual recognition mechanisms and mutual trust, but at the same time showed that it is willing to scrutinise EU measures based on these mechanisms in-depth. Avotiņš v. Latvia, no. 17502/07, ECLI:CE:ECHR:2016:0523JUD001750207, para. 113. L GLAS and J KROMMENDIJK, above $\mathrm{n}$ xx.

${ }^{5}$ The case law of the ECtHR on Article 267 TFEU seems to change the nature of the preliminary reference procedure from a mechanism of inter-judicial cooperation to a mechanism safeguarding the individual right to a fair trial. In doing so, the ECtHR is intruding with the 'specific characteristics and the autonomy of EU law'. These fears are, however, slightly exaggerated, as argued in J KROMMENDIJK, “'Open sesame!” Improving access to the CJEU by obliging national courts to reason their refusals to refer' (2017) 1 European Law Review 46.
} 
disappointment' and held that the 'the onus will be on the Strasbourg Court to do what it can in cases before it to protect citizens from the negative effects of this situation' ${ }^{6}$ Against this background it is not surprising that the official contacts between the CJEU and ECtHR were only resumed in March 2016 when a delegation of the ECtHR visited the CJEU. ${ }^{7}$ During this visit, judges of both courts talked about the two challenging issues identified above: the preliminary ruling procedure and the Dublin System in the light of the ECHR. ${ }^{8}$

These tensions warrant the question as to whether Opinion $2 / 13$ has led to a changing dialogue or interaction between both courts. Before Opinion 2/13 academics and scholars alike championed the practice of extensive 'cross-fertilisation' and 'parallel interpretation'. ${ }^{9}$ By contrast, the developments sketched above seem to suggest that we might have entered a new period of increasing tensions between both courts. Opinion 2/13 could easily be interpreted as an illustration of the increasing alleingang of the CJEU whereby the CJEU primarily tries to come up with its own autonomous interpretation on the basis of the EU Charter of Fundamental Rights, thereby sidelining the ECHR and the case law of ECtHR. ${ }^{10}$ This has also been the perception in Strasbourg. The 2016 report on the future of the ECHR of the Steering Committee for Human Right referred to 'growing importance of the Charter [...] to the detriment of the Convention'. ${ }^{11}$ There is also a 'corridor joke' in the CJEU that Strasbourg is almost begging the Court of Justice to cite it. ${ }^{12}$

But is it truly so that the CJEU has begun to cite the ECtHR less often and in different ways since Opinion 2/13? This chapter examines the case law of the CJEU after Opinion 2/13 in order to identify how the CJEU has dealt with the jurisprudence from Strasbourg and whether there has been a marked change since Opinion 2/13. This chapter will build on earlier published work examining the interaction between both European (human rights) systems. ${ }^{13}$ An earlier article focused on the way in which the case law of the ECtHR was used by CJEU judges, Advocates-General (AGs) and référendaires

\footnotetext{
${ }^{6}$ ECtHR, Annual report 2014. <www.echr.coe.int/Documents/Annual_Report_2014_ENG.pdf>, p. 6. The ECtHR (Grand Chamber), nonetheless, recently upheld its Bosphorus doctrine despite assertions in the literature that it might choose to drop it in the light of Opinion 2/13. See Avotiņš v. Latvia, no. 17502/07, ECLI:CE:ECHR:2016:0523JUD001750207. For a full discussion of this judgment, see L GLAS and J KROMMENDIJK, 'From Opinion 2/13 to Avotinšs: Recent Developments in the Relationship between the Luxembourg and Strasbourg Court' (2017) 2 Human Rights Law Review.

${ }^{7}$ President of the ECtHR Spielmann held in October 2015 that official contacts had yet to resume. D SPIELMANN, 'Whither judicial dialogue', Sir Thomas More lecture Lincoln's Inn, 12 October 2015.

${ }^{8}$ They also had a general discussion about the recent case law of both courts. See CJEU, 'A delegation from the European Court of Human Rights visits the Court of Justice of the European Union', Press release no. 25/16, 7 March 2016, <curia.europa.eu/jcms/upload/docs/application/pdf/2016-03/cp160025en.pdf>.

${ }^{9}$ F G JACOBS, 'Judicial dialogue and the cross-fertilization of legal systems: the European Court of Justice' (2003) Texas International Law Journal 547; Joint communication from Presidents Costa and Skouris, 24 January 2011, <curia.europa.eu/jcms/upload/docs/application/pdf/2011-02/cedh_cjue_english.pdf>, para. 1.

${ }^{10}$ Case C-617/10, Akerberg Fransson, ECLI:EU:C:2013:105, para. 87. Some Advocates General have also been relatively open about the need for an autonomous interpretation. Opinion of Advocate General Poiares Maduro in Case C-465/07, Elgafaji, ECLI:EU:C:2008:479, para. 19-20; Opinion of Advocate General Cruz Villalón in Case C-69/10, Samba Diouf, ECLI:EU:C:2011:102, para. 39.

${ }^{11}$ Steering CommitTeE For Human Rights (CDDH), 'Report on the longer-term future of the system of the European Convention on Human Rights', CM(2015)176-add1final, 3 February 2016, para. 179.

${ }^{12}$ Interviews as discussed in J KROMMENDIJK, above $\mathrm{nxx}, \mathrm{p} 826$.

${ }^{13}$ This chapter is partly based on earlier work with a more limited time period until June 2016 (in Dutch); J KROMMENDIJK, 'Het Hof van Justitie van de EU en de rechtspraak van het EHRM sinds Advies 2/13. Een toenemende alleingang en autonome aanpak?' (2016) 8 Asiel \& Migrantenrecht, 356-361; See also L GLAS and J KROMMENDIJK, above n xx.
} 
on the basis of twenty interviews with these Luxembourg insiders. ${ }^{14}$ This chapter will reflect on these findings on the basis of a structured legal analysis of CJEU judgments following the 2.5 years after Opinion $2 / 13 .{ }^{15}$

It is not easy to answer the central research question with great certainty, also given the short period of time that has lapsed since Opinion 2/13. In addition, examining from a more quantitative view whether Opinion 2/13 has resulted in a lower number of references to ECtHR does not tell very much, especially for such a short period of time. ${ }^{16}$ This is also because the CJEU has no control over its case docket and the number of references to ECtHR also depend on the number of fundamental rights relates cases that reach the CJEU in the first place. It is thus only possible to come up with some tentative observations and trends. Time will tell whether those trends will also result in a more solid practice.

This chapter starts with a short sketch of the legal framework as to the relevance of the ECHR and judgments of the ECtHR for the EU legal order and the CJEU. Section 2 provides a typology of different ways in which the CJEU has referred to the ECtHR or refrained from doing so. The concluding section 3 reflects on the main research question as to whether Opinion 2/13 has been a game changer or not and what the implications of the CJEU's case law are for future accession of the EU to the ECHR.

\section{Legal framework ${ }^{17}$}

Before examining the actual practice of reliance on the case law of the ECtHR, it is important to pay attention to the legal framework governing the relevance of the ECHR and the case law of the ECtHR for the EU. The EU is not yet legally bound to comply with the ECHR nor the judgments of the ECtHR. In Åkerberg Fransson and Kamberaj the CJEU determined that the ECHR 'does not constitute, as long as the European Union has not acceded to it, a legal instrument which has been formally incorporated into European Union law'. ${ }^{18}$ The CJEU has reiterated this postulation post-Opinion 2/13 in several judgments, such as Inuit Tapiriit Kanatami and J.N.. ${ }^{19}$ The CJEU suggested in Opinion 2/13 that the ECtHR's interpretation of the ECHR is only binding upon the EU after the EU's accession to the ECHR,

\footnotetext{
${ }^{14} \mathrm{~J}$ KROMMENDIJK, above $\mathrm{n} \mathrm{xx}$.

15 These judgments were found by searching curia with references to the "European Court of Human Rights" in the period between 19 December 2014 and 19 June 2017 for the Court of Justice only, thereby excluding the General Court and the Civil Service Tribunal from the analysis. This led to 138 documents in 98 different cases, including judgments/ orders or AG Opinions. All these documents were examined and AG Opinions were compared with the CJEU judgments in the respective cases.

${ }^{16}$ Two examples of more quantitative approaches are De Búrca, who examined the period between 2009 and 2012 and found less references to the ECtHR. In addition, Eckes found more references to the ECHR (the Convention instead of the ECtHR) in the period between 2010-2012 than in the period between 2007-2009. G DE BÚRCA, 'After the EU Charter of Fundamental Rights: The Court of Justice as a Human Rights Adjudicator' (2013) Maastricht Journal of European and Comparative Law 168, 174-176; C ECKES, 'The Court of Justice's participation in the judicial discourse: theory and practice', in M. Cremona and A THIEs (eds), The European Court of Justice and External Relations - Constitutional Challenges, Hart 2014.

${ }^{17}$ This section is for a large part based on J KROMMENDIJK, above $\mathrm{nxx}, \mathrm{p}$ 814-816.

${ }^{18}$ Case C-617/10, Åkerberg Fransson, ECLI:EU:C:2013:105, para. 44; Case C-571/10 Kamberaj, ECLI:EU:C:2012:233, para. 60.

${ }^{19}$ Case C-398/13 P, Inuit Tapiriit Kanatami, ECLI:EU:C:2015:535, para. 45; Case C-601/15 PPU, J.N., ECLI:EU:C:2016:84, para. 45.
} 
even though there was (and still is) some discussion as to whether this is really the case.$^{20}$ In sum, at the moment, the EU is not (yet) bound by the ECHR and the ECtHR.

This is, however, not the full story. As the CJEU emphasised in several cases as well, Article 6(3) TEU confirms that fundamental rights recognised by the ECHR constitute general principles of EU law. ${ }^{21}$ In addition, it noted that Article 52(3) requires that ECHR-corresponding rights in the Charter are given the same meaning and scope as those laid down by the ECHR. ${ }^{22}$ Article 52(3) does, however, not refer to the case law of the ECtHR. This was intentionally left out in order to safeguard the autonomy of the CJEU. ${ }^{23}$ Only the Explanations to Article 52(3) make a reference to the ECtHR. The Explanations stipulate that: 'the meaning and the scope of the guaranteed rights are determined not only by the text of those instruments, but also by the case law of the European Court of Human Rights'. The Explanations are, however, not legally binding, but should only 'be given due regard' to on the basis of Articles 52(7) of the Charter and 6(1) TEU. There are, however, some early Charter cases in which the CJEU seemed to interpret Article 52(3) more broadly and attached more legal value to the case law of the ECtHR. In $M c B$ the CJEU, for example held that the Charter must 'be given the same meaning and the same scope as Article 8(1) of the ECHR, as interpreted by the case law of the European Court of Human Rights'. ${ }^{24}$ Since Opinion 2/13, the CJEU has been more nuanced and has held that Article 52(3) merely obliges the CJEU to 'take into consideration' case law of the ECtHR when interpreting the Charter which reflects more an obligation of conduct. ${ }^{25}$ Nonetheless, in some judgments, including WebMindLicenses

\footnotetext{
${ }^{20}$ Opinion 2/13, ECLI:EU:C:2014:2454, para. 185; During the hearings in the context of Opinion 2/13 there was 'extensive discussion' as to whether the CJEU -after accession of the EU to the ECHR-could refuse to recognise judgments of the ECtHR where these conflict with the constitutional identity of the EU or where they are ultra vires. See AG Kokott in Opinion 2/13, ECLI:EU:C:2014:2475, para. 167-171. The CJEU seemed to imply that such situations might indeed occur, because it held that 'it should not be possible for the ECtHR to call into question the Court's finding in relation to the scope ratione materiae of EU law'. Opinion 2/13, para. 186. Note that even following accession, the CJEU is still not formally bound to the entire case law of the ECtHR, since Article 46(1) ECHR stipulates that judgments are binding inter partes (res judicata). In addition, judgment are declaratory in nature. AG Kokott in Opinion 2/13, paras. 78 and 123. See also Kadi I in which the CJEU held that UN Security Council Resolutions cannot derogate from the 'very foundations of the Community legal order' and cannot have primacy over general principles of EU law. Joined Cases 402/05 P and C-415/05 P, Kadi, ECLI:EU:C:2008:461 paras. 304-308. ECtHR judgments are at the same time considered to have res interpretata, which means that an interpretation of the ECHR by the ECtHR that can be generalised beyond the concrete case is part of the ECHR and because of that binding on State Parties. A Bodnar, 'Res Interpretata: Legal Effect of the European Court of Human Rights' Judgments for other States Than Those Which Were Party to the Proceedings' (2014) Ius Gentium: Comparative Perspectives on Law and Justice 223.

${ }^{21}$ E.g. Tapiriit Kanatami and J.N. De Witte argued on the basis of Article 6(3) TEU that the EU is already bound by the ECHR without accession of the EU to the ECHR. B DE WITTE, 'The use of the ECHR and Convention case law by the European Court of Justice', in P POPELIER et al. (eds), Human rights protection in the European legal order: the interaction between the European and the national courts, Intersentia, Cambridge 2011, pp 17-34, 21-22.

${ }^{22}$ Article 52(3) provides: 'In so far as this Charter contains rights which correspond to rights guaranteed by the Convention for the Protection of Human Rights and Fundamental Freedoms, the meaning and scope of those rights shall be the same as those laid down by the said Convention. This provision shall not prevent Union law providing more extensive protection.' Advocate General Kokott labeled Article 52(3) of the Charter as a 'homogeneity clause'. Opinion of Advocate General Kokott in Case C-109/10 P, Solvay v. Commission, ECLI:EU:C:2011:686, para. 252.

${ }^{23}$ S DougLAS-SCOTT, 'The Court of Justice of the European Union and the European Court of Human Rights after Lisbon', in S DE VRIES et al. (eds), The Protection of Fundamental Rights in the EU after Lisbon, Hart 2013, pp 153-179, 163.

${ }^{24}$ Case C-400/10 PPU, McB, ECLI:EU:C:2010:582, para. 53; C-279/09 DEB ECLI:EU:C:2010:811, para. 35. The CJEU determined in Arango Jaramillo that 'reference must be made' to the case law of the ECtHR in accordance with Article 52(3) of the Charter. Case C-334/12 RX-II, Arango Jaramillo and others v. EIB, ECLI:EU:C:2013:134, para. 43.

${ }^{25}$ Case C-239/14, Tall, ECLI:EU:C:2015:824, para. 54; Case C-601/15 PPU, J.N., ECLI:EU:C:2016:84, para. 44; Case C-398/13 P, Inuit Tapiriit Kanatami, ECLI:EU:C:2015:535, para. 61.
} 
and Toma, the CJEU followed and explicitly cited the seemingly more far-ranging $M c B$ reading of Article 52(3) and framed more in terms of an obligation of result. ${ }^{26}$

The CJEU has become more reluctant to attach importance to the case law of the ECtHR from a formal point of view in other respects as well. Before December 2014, the CJEU already held several times that: 'Article 47 of the Charter secures in EU law the protection afforded by Article 6(1) of the ECHR. It is necessary, therefore, to refer only to Article $47^{\prime} \cdot{ }^{27}$ The CJEU later applied this logic to other Charter provisions in Inuit Tapiriit Kanatami II when it held that it was appropriate for the General Court to solely examine the validity of the basic regulation on the basis of Articles 17, 7, 10 and 11 of the Charter. ${ }^{28}$ In J.N., the CJEU added that the review of the validity of EU secondary law 'must be undertaken solely in the light of the fundamental rights guaranteed by the Charter'. ${ }^{29}$ With this conclusion, the CJEU went further than its previous case law in two respects. Firstly, by using such demanding language ('must') and, secondly, by referring to the Charter in general without signalling out specific provisions. So it is no longer only Article 47 of the Charter, that has a wider scope than the ECHR, that could (and must!) be interpreted autonomously, but also provisions that have the same scope and meaning as ECHR provisions. ${ }^{30}$

The CJEU also downplayed the relevance of Article 52(3) in J.N. in another way. It emphasised that consistency between the Charter and the ECHR should be sought 'without thereby adversely affecting the autonomy of Union law and ... that of the Court of Justice of the European Union'. J.N. was the first time that the CJEU quoted this sentence from the Explanations to Article 52(3), which clearly echoes the tone of Opinion $2 / 13 .{ }^{31}$ The CJEU subsequently determined that 'an EU measure must be interpreted, as far as possible, in such a way as not to affect its validity and in conformity with primary law as a whole and, in particular, with the provisions of the Charter'. J.N. is thus a good recent example of so-called 'Charter-centrism' which places the Charter centre stage. ${ }^{32}$ It also reflects a wish among CJEU judges and référendaires that the importance, the autonomy and the higher level of protection of the EU's 'own catalogue' should be underlined by citing Strasbourg less often. ${ }^{33}$

\footnotetext{
${ }^{26}$ Case C-205/15, Toma, ECLI:EU:C:2016:499, para. 41; Case C-419/14, WebMindLicenses Kft., ECLI:EU:C:2015:832, para. 70. Note that AG Wathelet merely held in this case that 'reference should be made' to the ECtHR case law which 'could be useful'. Opinion of AG Wathelet in Case C-419/14, WebMindLicenses Kft., ECLI:EU:C:2015:606, paras. 110 and 113.

27 E.g. Case C-386/10 P, Chalkor v. Commission, ECLI:EU:C:2011:815, para. 51; Case C-199/11, Otis and others, ECLI:EU:C:2012:684, para. 47; Case C-396/11, Radu, ECLI:EU:C:2013:39, para. 32.

${ }^{28}$ Case C-398/13 P, Inuit Tapiriit Kanatami, ECLI:EU:C:2015:535, para. 46

${ }^{29}$ Case C-601/15 PPU, J.N., ECLI:EU:C:2016:84, para. 46.

${ }^{30}$ Article 47 offers more protection than Article 13 and 6(1) ECHR since Article 47(1) protects the right to an effective remedy before a court and because the right to a fair hearing in Article 47(2) is not confined to civil law disputes. For an overview of Charter articles corresponding to or with a wider scope than the ECHR, see the Explanations to the Charter. (2007/C 303/02), $17-18$.

${ }^{31}$ Note that the CJEU already held in Elgafaji in relation to Article 15(c) of the Qualification Directive that it 'is a provision, the content of which is different from that of Article 3 of the ECHR, and the interpretation of which must, therefore, be carried out independently, although with due regard for fundamental rights, as they are guaranteed under the ECHR'. C-465/07, Elgafaji, ECLI:EU:C:2009:94, para. 28.

${ }^{32}$ K LenAerts and J A GutiérRez Fons, 'The Place of the Charter in the EU Constitutional Edifice', in S PEERS et al. (eds), The EU Charter of Fundamental Rights: A Commentary, Hart 2014, pp 1559-1593, margin note 55.26; S IGLESIAS SÁNCHEZ, 'The Court and the Charter: The impact of the entry into force of the Lisbon Treaty on the ECJ's approach to fundamental rights' (2012) Common Market Law Review 1565, 1601.

${ }^{33}$ Interviews as discussed in J KROMMENDIJK, above n xx, 832
} 
Since J.N. conflicting judgment have been rendered in which the CJEU reflected explicitly on the relationship between the Charter and the ECHR as well as Article 52(3). Some judgments repeated several of the considerations of J.N. and the 'must ... solely' interpret logic. ${ }^{34}$ Several others, however, took a more ECHR-friendly approach, some of those referring to $M c B$ or $D E B$ instead. ${ }^{35}$ It is not entirely clear how both strands fit together, but it seems that the J.N. approach is more dominant, also because this was a judgment of the Grand Chamber while the others were not. In addition, the more restricted interpretation of Article 52(3) which only obliges to 'take into account' the case law of the ECtHR is consistent with the interviews with Luxembourg insiders who tended to exclude any formal legal binding force given to ECtHR judgments. ${ }^{36}$

\section{A post-Opinion 2/13 typology of the practice of citing Strasbourg}

Despite the formal reluctance to acknowledge the case law of the ECtHR, the CJEU has continued citing the ECtHR, even in Inuit Tapiriit Kanatami II and J.N. in which the CJEU was particularly dismissive about the need to rely on Strasbourg. ${ }^{37}$ This section provides an overview of CJEU judgments which referred or could have referred to the case law of the ECtHR. It will distinguish between five categories: extensive reliance on Strasbourg (section 2.1), (passing) references to the ECtHR (section 2.2), references to the ECtHR as afterthought (section 2.3), CJEU judgments without any references to the ECtHR (section 2.4) and CJEU judgments which do not engage with (the Charter of) fundamental rights at all (section 2.5). The last two types of CJEU judgment were primarily identified on the basis of the references to the ECtHR in the judgments and opinions found in Curia, either done by AGs, (one of) the parties and/or the referring court. ${ }^{38}$

As the rest of this section shows as well, the CJEU tends to refer to Strasbourg when this is strictly necessary, because there is a tendency to keep judgments as short as possible and there is an emphasis on solving the dispute. ${ }^{39}$ This idea is, for example, visible in the Opinion of AG Kokott in Inuit Tapiriit Kanatami II, who dismissed the applicants' ECHR argument on the grounds that they failed to explain the 'additional benefit' for considering the ECHR. She implied that a reference to the ECHR would only be warranted if the ECHR is imposing higher requirements than the Charter. ${ }^{40}$

\subsection{Extensive reliance on Strasbourg}

\footnotetext{
${ }^{34}$ Case C-203/15, Tele2 Sverige AB, ECLI:EU:C:2016:970, paras. 127-129; Case C-218/15, Paoletti, ECLI:EU:C:2016:748, para. 22.

${ }^{35}$ Case C-205/15, Toma, ECLI:EU:C:2016:499, para. 41; Case C-294/16 PPU, JZ, ECLI:EU:C:2016:610, paras. 48-50; Case C-528/15, Al Chodor, ECLI:EU:C:2017:213, para. 37.

${ }^{36}$ Interviews as discussed in J KROMMENDIJK, above $\mathrm{nxx}, 816$.

${ }^{37}$ In Inuit Tapiriit Kanatami II, the CJEU cited two judgments of the ECtHR to support its conclusion that future income cannot be considered possessions, 'unless it has already been earned, it is definitively payable or there are specific circumstances that can cause the person concerned to entertain a legitimate expectation of obtaining an asset'. Case C-398/13 P, Inuit Tapiriit Kanatami, ECLI:EU:C:2015:535, para. 61. For J.N., see below n xx.

${ }^{38}$ See above $\mathrm{n} x \mathrm{x}$ for a description of the performed database search.

${ }^{39}$ Interviews as discussed in J KROMMENDIJK, above $\mathrm{nxx}, 825-829$.

${ }^{40}$ Case C-398/13 P, Inuit Tapiriit Kanatami, ECLI:EU:C:2015:190, paras. 69-70
} 
There are several post-Opinion 2/13 judgments in which the case law of the ECtHR figures rather prominently. Two judgments, Aranyosi and C.K. stand out in particular, because the CJEU changed its approach, as set out in the introduction, in relation to the principle of mutual trust and the protection of individuals against inhuman and degrading. While in earlier judgments, the CJEU seemed to prioritize the former by only accepting that fundamental rights can rebut the presumption of mutual trust 'in exceptional circumstances', it seems to have realized that mutual trust is very much depended on the proper protection of fundamental rights. ${ }^{41}$ In Aranyosi, the CJEU opted for a more fundamental rights consistent reading of the Framework Decision on the European Arrest Warrant (EAW) by concluding that the execution of a EAW must be suspended if there is a real risk of inhuman or degrading treatment for the individual concerned because of deficient detention conditions in the requesting Member States. ${ }^{42}$ This ran counter to the heavily criticised opinion of AG Bot who prioritised mutual trust and did not refer to Article 52(3) and tried everything he could to stay within the confines of the EAW system and the limited grounds for non-execution. ${ }^{43}$ On the basis of the case law of ECtHR, the CJEU went even so far as to accept a 'positive obligation' to ensure that prison conditions are in line with fundamental rights. ${ }^{44}$ It is one of the very few judgments in which the CJEU subscribed in such explicit terms to an important doctrine developed by the ECtHR. ${ }^{45}$ Relying on Aranyosi and a considerable number of judgments of the ECtHR, the CJEU also opted for a more fundamental rights and ECHR friendly interpretation of the Dublin III Regulation in C.K. ${ }^{46}$ Just like Aranyosi, the CJEU again took a different stance than the AG, Tanchev, who explicitly held that the CJEU is not required to follow the approach of the ECtHR. ${ }^{47}$ While the CJEU was only willing to admit the possibility for national courts to refuse to return an asylum seeker to the Member State in case of 'systemic flaws' in the asylum procedure and in the reception conditions in N.S., it now considered the individual risks for the asylum seeker to be decisive ${ }^{48}$ The CJEU thus accepted 'any circumstance other than' those systemic deficiencies, including those related to the state of health of the asylum seeker. In reaching this conclusion, the CJEU relied on the judgment of the ECtHR of two months earlier in Paposhvili dealing with the positive obligations of states to prevent refoulement of severely ill persons. ${ }^{49}$

\footnotetext{
${ }^{41}$ C RizCALlaH, 'The Dublin system: the ECJ squares the circle between mutual trust and human rights protection', 20 February 2017, EU Law Analysis.

42 Joined Cases C-404/15 and C-659/15 PPU, Aranyosi and Căldăraru, ECLI:EU:C:2016:198, paras. 86-91.

${ }^{43}$ See e.g. FAIR TRIALs, 'AG’s Bot Opinion in Aranyosi and Căldăraru. A threat to justice in Europe, <www.fairtrials.org/wpcontent/uploads/160310-Jourov\%C3\%A1.pdf?platform=hootsuite>.

${ }^{44}$ Ibid., para. 90.

${ }^{45}$ For an earlier precedent, see C-540/03, European Parliament v. Council, ECLI:EU:C:2006:429, paras. 54, 60 and 62.

${ }^{46}$ C RizCALLAH, above $\mathrm{n} x \mathrm{x}$.

47 The CJEU held that the case law of the ECtHR 'must be taken into account'. Case C-578/16 PPU, C.K., ECLI:EU:C:2017:127, para. 68; AG Tanchev in Case C-578/16 PPU, C.K., ECLI:EU:C:2017:108, para. 53.

${ }^{48}$ N.S. (and subsequent judgments such as Abdullahi and Kaveh Puid) were earlier criticized exactly on this point, because the CJEU came up with a (seemingly) more restrictive requirement of 'systemic flaws', which was considered to be at odds with the approach of the ECtHR in relation to article 3 ECHR for whom individual circumstances alone matter. M DEN HEIJER, Case Note on NS (2012) Common Market Law Review 1735, 1747. Joined Cases C-411/10 and C-493/10, N.S., ECLI:EU:C:2011:865. See, however, K LENAERTS, 'La vie après l'Avis: Exploring the principle of mutual (yet not blind) trust' (2017) Common Market Law Review 805, 832.

${ }^{49}$ Paposhvili v. Belgium, no. 41738/10, CE:ECHR:2016:1213JUD004173810, paras. 174 and 175.
} 
In WebMindLicenses, the CJEU is also very indebted to Strasbourg, at least in some parts of the judgment. After quoting the more Strasbourg friendly $M c B$ reading of Article 52(3), the CJEU cited no less than seven ECtHR judgments to supports its finding that the interception of telecommunications and seizure of emails constitutes an interference with Article 8 ECHR and consequently 'also' a limitation of the corresponding right laid down in Article 7 of the Charter. ${ }^{50}$ In addition, it also cited five Strasbourg judgments to underline that the absence of a prior judicial authorisation to obtain certain evidence must be compensated by a strict legal framework and procedural safeguards against arbitrary interferences and/ or effective ex post review. ${ }^{51}$ Without saying that the CJEU should have foregone a reference to Strasbourg, it is unclear why the CJEU felt it necessary to rely so extensively on the ECtHR and needed to quote so many judgments, also when comparing this judgment with other in which the CJEU did not make any references to the ECtHR (see section 2.4). With respect to the interception, the CJEU could simply have relied on its own extensive case law in the field of data protection, such as Digital Rights or Schrems. ${ }^{52}$ In relation to judicial authorisation a reference to Deutsche Bahn (discussed below) would have seemed appropriate (or sufficient) as well. ${ }^{53}$ In addition, the CJEU was not very consistent in its broad use of Strasbourg (see section 2.2. on the selective use of the ECtHR). With respect to the subsequent issue as to whether the transmission of the evidence by the criminal investigation department to the tax authorities, the CJEU held that only natural persons can invoke the protection of Article 8 of the Charter. This is contrary to the Opinion of AG Wathelet who relied on the case law of the ECtHR (and also the CJEU) suggesting that legal persons can also rely on Article 8 of the Charter and Article 8 ECHR. ${ }^{54}$ Nor did the CJEU (and the AG) justify its approach as to the use of evidence, which was obtained in violation of EU law and the Charter. This is surprising because the CJEU is considerably more strict from the point of view of fundamental rights protection than the ECtHR. It held, without reference to any precedent, that decisions based on wrongfully obtained evidence must simply be annulled. ${ }^{55}$ By contrast, the ECtHR only requires such an outcome when the infringement of privacy also violates the right to a fair trial as laid down in Article 6 ECHR. ${ }^{56}$

\footnotetext{
${ }^{50}$ Case C-419/14, WebMindLicenses Kft., ECLI:EU:C:2015:832, paras. 70-72.

${ }^{51}$ Ibid., paras. 77-78.

${ }^{52}$ See, however, Case C-203/15, Tele2 Sverige AB, ECLI:EU:C:2016:970, paras. 127-129; C-293/12 and C-594/12, Digital Rights Ireland and Others,EU:C:2014:238; C-362/14, Schrems, ECLI:EU:C:2015:627.

${ }^{53}$ M FierstrA, case note on Case C-419/14, WebMindLicenses Kft., European Human Rights Cases 2016/107. This judgment is obviously different since it deals with the Commission investigatory powers in the EU competition law context under Regulation 1/2003. Nonetheless, the CJEU subscribed more generally to the ECtHR approach in Société Colas Est. Case C583/13 P, Deutsche Bahn and others v. Commission, ECLI:EU:C:2015:404, paras. 17-37.

${ }^{54}$ Contrast Case C-419/14, WebMindLicenses Kft., ECLI:EU:C:2015:832, para. 79 with Opinion of AG Wathelet in Case C-419/14, WebMindLicenses Kft., ECLI:EU:C:2015:606, paras. 111-112. The CJEU referred to Volker as a relevant precedent, but the AG noted that subsequent judgments of the CJEU, such as Digital Rights, point in a different direction. C-92/09 and C93/09, Volker und Markus Schecke and Eifert, ECLI:EU:C:2010:662, paras. 52-53; C-293/12 and C-594/12, Digital Rights Ireland and Others,EU:C:2014:238, paras. 32-37.

${ }^{55}$ Case C-419/14, WebMindLicenses Kft., ECLI:EU:C:2015:832, para. 89. Fierstra criticised this limited reasoning also in the light of the principle of procedural autonomy, which the CJEU does not mention in this context either. M FIERSTRA, above $n$ $\mathrm{xx}$.

${ }^{56}$ Bykov v. Russia, no. 4378/02, ECLI:CE:ECHR:2009:0310JUD000437802, para. 89; Rywin v. Poland, nos. 6091/06, 4047/07 and 4070/07, ECLI:CE:ECHR:2016:0218JUD000609106, para. 72; ECtHR, P.G. and J.H. v. United Kingdom, no. 44787/98, ECLI:CE:ECHR:2001:0925JUD004478798, para. 34.
} 
There are several other good examples of cases in which the CJEU relies relatively extensively on the ECtHR which are worth to mention shortly. In Deutsche Bahn, the CJEU reviewed the consistency of the dawn raids conducted by the European Commission in the context of the enforcement of EU competition rules not only on the basis of the Charter, but also the ECHR and the case law of the ECtHR. The CJEU, interestingly enough, did not sketch the earlier discussed legal context for this reliance through, for instance, referring to Article 52(3) of the Charter. What is even more remarkable is that the CJEU even took the EC(t)HR as the starting point, since it first examined the compatibility of the CJEU's judicial review of Commission inspection decisions with Articles 8 and Article 6(1) ECHR before reaching the conclusion that there was no violation of Articles 7 and 47 of the Charter. ${ }^{57}$ Another case which runs counter to the earlier mentioned Charter-centrism is Evonik Degussa. The General Court primarily applied Article 8(1) ECHR instead of Article 7 of the Charter and found that the right to protection of privacy does not extend to reputational damage stemming from a person's own (criminal) conduct. ${ }^{58}$ In appeal, the CJEU also relied on the ECtHR even though it did not cite specific judgments. ${ }^{59}$ Another noteworthy judgment that extensively discussed the ECHR as well as the case law of the ECtHR is Tall in which the CJEU held that suspensory effect is not required for appeals against decisions not to further examine an asylum application when they do not lead to the removal of the person concerned. ${ }^{60}$ As a matter of fact, the CJEU went much further in this respect than AG who only mentioned the observation of the European Commission on the basis of the ECtHR that expulsion decisions must, in principle, have suspensory effects. ${ }^{61}$ In another EAW case, Lanigan, the CJEU also applied the case law of the ECtHR on Article 5(1)(f) ECHR on extradition procedures in the context of surrender procedures and held that detention of the requested person is not justified when that procedure is not carried out with due diligence. The CJEU subsequently enumerated several factors reminiscent of the ECtHR case law which national courts should take into account while conducting the latter review. ${ }^{62}$

\section{2. (Passing) references to the ECtHR}

In other cases, the CJEU has made shorter references to the case law of the ECtHR. The rest of this section will distinguish between four different types of references, albeit these are by no means (mutually) exhaustive: references in sensitive cases, citations when an EU law measure or Charter provision is interpreted for the first time, seemingly superfluous references and selective shopping in the case law of the ECtHR.

\footnotetext{
${ }^{57}$ Case C-583/13 P, Deutsche Bahn and others v. Commission, ECLI:EU:C:2015:404, paras. 32-36 and 46-48. M VEENBRINK and J KROMMENDIJK, case note on Case C-583/13 P, Deutsche Bahn, European Human Rights Cases 2015/187.

${ }^{58}$ Case T-341/12, Evonik Degussa, ECLI:EU:T:2015:51, paras. 123-126.

${ }^{59}$ Case C-162/15 P-R, Evonik Degussa, ECLI:EU:C:2016:142, para. 43.

${ }^{60}$ Case C-239/14, Tall, ECLI:EU:C:2015:824. Compare this judgment with Case C-562/13, Abdida, ECLI:EU:C:2014:2453.

${ }^{61}$ AG Cruz Villalón in Case C-239/14, Tall, ECLI:EU:C:2015:531, para. 34.

62 C-237/15 PPU, Lanigan, ECLI:EU:C:2015:474, paras. 59-60; Gallardo Sanchez v. Italy, no. 11620/07, ECLI:CE:ECHR:2015:0324JUD001162007, paras. 41-50.
} 
It is not surprising that references are especially made in sensitive or complex cases, where a reference to another supranational court could strengthen the arguments and conclusions of the CJEU. ${ }^{63}$ The best illustration of a post-Opinion 2/13 case in a sensitive area is Taricco. In this Grand Chamber judgment the CJEU, in line with AG Kokott, expanded the obligation for Member States to prosecute VAT fraud more effectively by setting aside an Italian rule which provided for strict limitation periods. In this case the CJEU referred to several judgments of the ECtHR in response to the observations of several interested parties that this might create tension with Article 49 of the Charter and the principle of legality. Relying on Strasbourg, the CJEU supported its conclusion that the disapplication of national law does not breach the rights of the accused. ${ }^{64}$ It does not seem unreasonable to infer that the CJEU aimed to divert some of the anticipated criticism with its reliance on another court. This criticism was indeed voiced afterwards. Taricco has been criticised for lowering the level of fundamental rights protection of suspects and easily disregarding the legal traditions of Member States which attach more importance to the principle of legality and offer more protection against retroactive changes of limitation periods. ${ }^{65}$ The heavy critique eventually spurred the Italian Constitutional Court to send another reference in which the CJEU was essentially asked to reconsider its judgment. ${ }^{66}$ Without touching upon the question whether this criticism is justified, the reliance on the ECtHR shows that Strasbourg could be useful in such a sensitive area as national criminal (procedural) law. ${ }^{67}$ Other cases where a reference to the ECtHR was especially useful are Neptune Distribution and CHEZ. In Neptune Distribution (and later Philip Morris), the CJEU held that commercial information is in principle covered by the freedom of expression in Article 11 of the Charter. ${ }^{68}$ The CJEU in essence recognized a corporate human rights to freedom of expression, a notion which is controversial and has been criticized. ${ }^{69}$ In addition, another

\footnotetext{
${ }^{63}$ The landmark judgments in Kadi I and N.S. are good examples of this. Joined Cases C-402/05 P and C-415/05 P, Kadi I, ECLI:EU:C:2008:461; Joined Cases C-411/10 and C-493/10, N.S., ECLI:EU:C:2011:865. S IgLESIAS SANCHEZ, above $\mathrm{n} x \mathrm{x}$, 1604; K LENAERTS, 'Interlocking Legal orders in the European Union and comparative law' (2003) International and Comparative Law Quarterly 873, 875.

${ }^{64}$ Case C-105/14, Taricco, ECLI:EU:C:2015:555, para. 57. The CJEU also relied on the case law of the ECtHR in relation to the principle of legality in Case C-72/15, Rosneft, ECLI:EU:C:2017:236, paras. 164-166.

${ }^{65}$ E.g. M LASSALLE, 'Taricco kills two birds with one stone for the sake of the PIF', 27 October 2015, European Law Blog; D SARMIENTO, 'The scope of application of EU law and national criminal law: some thoughts on Taricco', 8 September 2015, <despiteourdifferencesblog.wordpress.com>; E BILLIS, "The European Court of Justice: a "quasi-constitutional court" in criminal matters?' (2016) New Journal of European Criminal Law 20.Timmerman, however, argued that the CJEU provided an interpretation in conformity with the ECtHR, but which is merely providing the minimum standard of protection and which thus consciously chose not to go beyond the level of protection under the ECHR. M TIMMERMAN, 'Balancing effective criminal sanctions with effective fundamental rights protection in cases of VAT fraud: Taricco' (2016) 3 Common Market Law Review 779 .

${ }^{66}$ L S Rossi, 'How Could the ECJ Escape from the Taricco Quagmire?', 21 April 2017, Verfassungsblog.

${ }^{67}$ Billis, who is of the opinion that Taricco is not in line with the ECtHR case law, noted that the quoted judgement of the ECtHR paradoxically underscores strict limitation periods and rejects unforeseeable rules E BILLIS, above n xx, 34 .

${ }^{68}$ Nonetheless, the CJEU eventually considered the French measure which obliged Neptune Distribution to remove misleading claims about low levels of sodium in natural mineral water from packages to be justified and proportional. C-157/14, Neptune Distribution, ECLI:EU:C:2015:823, para. 64. In Philip Morris, the CJEU even referred to the case law of the ECtHR without citing a particular judgment. Case C-547/14, Philip Morris, ECLI:EU:C:2016:325, para. 147.

${ }^{69}$ E.g. recently A SANCHEZ-GRAELLS and F Marcos, 'Human rights' protection for corporate antitrust defendants: Are we not going overboard?, in: P NiHOUL and T SKосZNY (eds), Procedural fairness in competition proceedings, Edward Elgar 2015, pp 84-107; T ISIKSEL, 'The rights of man and the rights of the man-made: Corporations and human rights' (2016) 2 Human Rights Quarterly 294.
} 
sensitive matter where the ECtHR has a lot of experience is the discrimination facing Roma. ${ }^{70}$ In $C H E Z$, the CJEU thus referred to two judgments in relation to the concept of ethnicity and its application to the Roma community. ${ }^{71}$

Covaci is the best example of a judgment in which the CJEU relied on Strasbourg when it interpreted an EU law measure or Charter provision for the first time. In the first judgment about the Roadmap Directives on procedural safeguards in criminal proceedings the CJEU made a short reference to an ECtHR judgment about the absence of a necessity to provide a written translation of all items of written evidence or official documents. ${ }^{72}$ It is, however, unclear why the CJEU made a reference to such an old Strasbourg precedent and did not rely on more recent Grand Chamber judgments of the ECtHR on this matter. ${ }^{73}$

In other cases the CJEU referred to Strasbourg, but it was not always clear why this reference was needed, at least if one is convinced of the argument that the CJEU applies a Charter-centred approach. An example is Neptune Distribution, where the CJEU relied on the ECtHR (a second time) to support its finding that correct information about the contents of products for consumers is closely related to the protection of human health and which is thus a question of general interest. ${ }^{74}$ This support from Strasbourg seems superfluous because of the ample case law of the CJEU in which it came to similar conclusion. ${ }^{75}$ Nor was the CJEU doing very much with this reference in its review of the French interference in Neptune Distribution. Likewise, the CJEU referred to the ECtHR in Nikolajeva in support of its consideration that an application for registration of a trade mark constitutes a substantive interest protected under the fundamental right to property, while it could have easily based itself on its own case law. $^{76}$

One example of selective shopping in the case law of the ECtHR is the politically controversial headscarves case of Achbita. ${ }^{77}$ In this judgment, the CJEU favoured the employer's wish to project an image of neutrality towards customers as part of an employer's freedom to conduct a business as laid down in Article 16 of the Charter over an individual's right to freedom of religion. ${ }^{78}$ The CJEU justified the following conclusion with a selective reference to the judgment of the ECtHR in Eweida: 'An interpretation to the effect that the pursuit of that aim allows, within certain limits, a restriction to be

\footnotetext{
${ }^{70}$ AG Kokott in Case C-394/11, Belov, ECLI:EU:C:2012:585, para. 3.

${ }^{71}$ Case C-83/14, CHEZ Razpredelenie Bulgaria, ECLI:EU:C:2015:480, para. 46.

72 Case C-216/14, Covaci, ECLI:EU:C:2015:686, para. 39; ECtHR, Kamasinski v. Austria, no. 9783/82, ECLI:CE:ECHR:1989:1219JUD000978382.

${ }^{73}$ Hermi v. Italy, no. 18114/02, ECLI:CE:ECHR:2006:1018JUD001811402.

${ }^{74}$ Case C-157/14, Neptune Distribution, ECLI:EU:C:2015:823, para. 74.

${ }^{75}$ E.g. Case C-544/10, Deutsches Weintor, ECLI:EU:C:2012:526, paras. 50-52. This judgment was referred to four times by the CJEU.

${ }^{76}$ Case C-280/15, Nikolajeva, ECLI:EU:C:2016:467, para. 43; Case C-580/13, Coty Germany, ECLI:EU:C:2015:485. By contrast, the CJEU recognized for the first time, at least to the author's knowledge, that the rights resulting from payment to contributions to a social security scheme constitute property rights with reference to three judgments of the ECtHR. Case C258/14, Florescu, ECLI:EU:C:2017:448, para. 50.

${ }^{77}$ See more in depth S OuALD-CHAIB and V DAVID, European Court of Justice keeps the door to religious discrimination in the private workplace opened. The European Court of Human Rights could close it', 27 March 2017, Strasbourg Observers Blog.

${ }^{78}$ G DAVIES, ‘Achbita v G4S: Religious equality squeezed between profit and prejudice', 6 April 2017, European Law Blog.
} 
imposed on the freedom of religion is moreover, borne out by the case-law of the European Court of Human Rights in relation to Article 9 of the ECHR. ${ }^{79}$ The CJEU, however, failed to pay any attention to the fair balance test required by the ECtHR and the fact that the ECtHR was actually very strict in accepting interferences with the freedom of religion in Eweida. The judgment of the CJEU does not seem to fit well with the conclusion of the ECtHR, in the same paragraph as quoted in Achbita, in relation to the British employer's neutrality policy that 'while this aim was undoubtedly legitimate, the domestic courts accorded it too much weight' ${ }^{80}$

\subsection{The ECtHR as afterthought}

In a third category of cases, the ECtHR is not part of the considerations which led to the conclusion of the CJEU, but is only mentioned at the end of the judgment as some sort of afterthought or cross-check to support the CJEU's own conclusions. This means that the 'Strasbourg-proofness' of the CJEU's analysis is mentioned at the end as a 'by the way' note. ${ }^{81}$ These judgments also underline the CJEU's wish to firstly develop its own autonomous (Charter) interpretation instead of simply relying on another court. The best illustration is J.N. which deals with detention of asylum seekers in the context of their deportation for reasons of public order and security. The CJEU went to great lengths to examine whether detention is valid in the light of Article 6 of the Charter laying down the right to liberty following a careful and detailed proportionality assessment in the context of Article 52(1) of the Charter. ${ }^{82}$ The CJEU, however, had to somehow reflect upon the case law of Strasbourg, because the referring Dutch court had explicitly asked about the validity of the Reception Conditions Directive in the light of one specific judgment of the ECtHR. The CJEU did so, but only at the end as a clear afterthought: 'Finally, it must be recalled that.... ${ }^{83}$ The approach of the CJEU can be contrasted with the Opinion of AG Sharpston who analysed Article 5 ECHR and Article 6 of the Charter in a more combined fashion and did not solely restrict herself to an analysis of Article 5(1)(f) ECHR, but also considered the other exemptions under Article 5(1) ECHR. ${ }^{84}$

This marginal cross-check relates to another practice whereby the CJEU cites the ECtHR in order to argue why a certain EU practice is not contrary to the ECHR. ${ }^{85}$ The CJEU, for example, held in the

\footnotetext{
${ }^{79}$ Case C-157/15, Achbita, ECLI:EU:C:2017:203, para. 39; Eweida and Others v. United Kingdom, nos. 48420/10, 36516/10, 51671/10 and 59842/10, CE:ECHR:2013:0115JUD004842010, para. 94.

${ }^{80}$ Ibid, para. 94.

${ }^{81}$ Case C-217/15, Orsi, ECLI:EU:C:2017:264, paras. 24-25; Case C-294/16 PPU, JZ, ECLI:EU:C:2016:610, para. 48; Case C-105/14, Taricco, ECLI:EU:C:2015:555, para.. 57; AG Wathelet in Joined Cases C-401/15 to C-403/15, Depesme, ECLI:EU:C:2016:430, para. 58. Interviews as discussed in J KROMMENDIJK, above $\mathrm{n} x \mathrm{x}, 832$.

${ }^{82}$ Case C-601/15 PPU, J.N., ECLI:EU:C:2016:84, paras. 50-76.

${ }^{83}$ Ibid., para. 77.

${ }^{84}$ AG Sharpston in Case C-601/15 PPU, J.N., ECLI:EU:C:2016:85, paras. 58, 60 and 117-215. This difference is also clear from a more quantitative point. AG Sharpston refers to 54 times to the ECHR (32 times to ECtHR) and 57 times to the Charter, while the CJEU judgments contains 21 references to the 21, 3 references to the ECtHR and 39 to the Charter. Note that doubts have been expressed as to the alleged lower level of protection offered by the CJEU. M RHIMES, 'Freedom, Asylum Seekers, and Two Lots of European Human Rights', 17 February 2016, UK human rights blog.

${ }^{85}$ Interviews as discussed in J KROMMENDIJK, above $\mathrm{n} \mathrm{xx}$, 830. In Bonda, the CJEU also held the administrative nature of the measures provided for in the relevant Regulation 'is not called into question by an examination of the case-law of the European
} 
context of EU competition law that the case law of the ECtHR with respect to Article 6 ECHR, more in particular the Menarini judgment, does not preclude a 'penalty' from being imposed by an administrative authority (the Commission) in the first instance when such a penalty can be reviewed by a judicial body (the CJEU) that has full jurisdiction and can quash the decision of the authority. ${ }^{86}$ The extensive reference to Strasbourg in Deutsche Bahn also falls into this category. The CJEU went to great lengths to argue that the system of dawn raid complies with fundamental rights. ${ }^{87}$ It held that Article 6 ECHR is not infringed by the ex post legal and factual review by the CJEU of inspection decisions which could lead to its annulment as a result of which the Commission is unable to use the gathered information.

\subsection{No references to the ECtHR}

There are several judgments in which the CJEU omits any reference to Strasbourg even though this would have been possible and perhaps even appropriate. This section, firstly, discusses judgments in which an absence of Strasbourg is understandable. Secondly, judgments in which a reference was possible.$^{88}$ Thirdly, judgments where a reference would seem appropriate.

Firstly, in some judgments, the lack of references is understandable. ${ }^{89}$ For example, in Léger the CJEU held that the permanent deferral from blood donation for men who have had sexual relations with other men may be justified only when there are no effective and less onerous alternatives in the form of detection techniques that also ensure a high level of health protection for blood recipients. There is no Strasbourg precedent on the specific point of blood bans, but even more generally it could be argued that there is not inspiration to derive from the ECtHR case law, since the ECtHR is generally considered to lag behind the CJEU in terms of protecting LGBT rights. ${ }^{90}$ Another example is Genc about the application of the standstill clause in the EU-Turkey Association Agreement. ${ }^{91}$ This case dealt with a Danish measure which made family reunification between a lawfully residing Turkish worker and his minor child subject to the condition that the latter has (the possibility of establishing) sufficient ties with Denmark to enable him successfully to integrate. The referring court explicitly referred to the case law of the ECtHR with respect to the right to family life in relation to the proportionality assessment. Both the CJEU and the AG did not refer to fundamental rights or the Charter, because the standstill clause offered higher protection than the ECHR.

\footnotetext{
Court of Human Rights on the concept of "criminal proceedings" within the meaning of Article 4(1) of Protocol No 7'. Case C-489/10, Bonda, ECLI:EU:C:2012:319, para. 36.

${ }^{86}$ Menarini Diagnostics v. Italy, no. 43509/08, ECLI:CE:ECHR:2011:0927JUD004350908; Case C-501/11 P, Schindler, ECLI:EU:C:2013:522, para. 35-39; Case C-510/11 P, Kone, ECLI:EU:C:2013:696, para. 22.

${ }^{87}$ A STEEnE, 'Nexans, Deutsche Bahn, and the CJEU's refusal to follow ECHR case law on dawn raids' (2016) Journal of European competition law \& practice $1,14$.

${ }^{88}$ For this argument in relation to the right to property, see P OLIVER AND C STOTHERS, 'Intellectual property under the Charter: are the Court's scales properly calibrated' (2017) Common Market Law Review 517, 541.

${ }^{89}$ E.g. when the CJEU could not deal with the merits of the case in appeal. Case C-176/13, Council v. Bank Mellat, ECLI:EU:C:2016:96, paras. 51-52; Case C-200/13, Council v. Bank Saderat Iran, ECLI:EU:C:2016:284, para. 49.

${ }^{90}$ P DunNe, 'A right to donate blood? Permanent deferrals for "Men who have Sex with Men” (MSM): Léger' (2015) Common Market Law Review 1661, 1676.

${ }^{91}$ C-561/14, Genc, ECLI:EU:C:2016:247.
} 
Secondly, without suggesting that the CJEU should have referred to the ECtHR, a potential for invoking Strasbourg exists when the referring court explicitly referred to the case law of the ECtHR or when the AG makes references to the ECtHR. ${ }^{92}$ The latter happened, for example, in relation to the sanctioning powers of the Commission in the context of competition law (InnoLux), the right to avoid self-incrimination (HeidelbergCement), the use of presumptions (Anbouba), the right to appeal (Imtech), the Brussel II bis Regulation and child abduction (Bradbrooke), the revocation of residence permit (H.T.), conscientious objection to military service (Shepherd), the disqualification of judges when they expressed provisional opinions (Ogynyanov), the right to a remedy against a decision to transfer of an asylum seeker (Ghezelbash), pre-surrender detention (Vilkas) and the freedom of religion (Bougnaoui) ${ }^{93}$ It is not always clear why the CJEU found it unnecessary to explicitly cite an ECtHR judgment in these (and other) cases. It could be that the CJEU simply agrees with the AG, but does not find it necessary to repeat the AG's analysis and citations of ECtHR. ${ }^{94}$ Or it could be that the CJEU disagrees with the AG.

It is worthwhile to discuss a judgment where a reference to the ECtHR would have been possible, but not necessary indispensable. In Schrems, the CJEU declared the Commission's US Safe Harbour decision, determining that the US offers an adequate level of protection of the personal data transferred, invalid in the light of Articles 7,8 and 47 of the Charter, dealing with respect for private and family life, the protection of personal data and the right to effective judicial protection. ${ }^{95}$ Schrems can be contrasted with WebMindLicenses in which the CJEU made rather extensive references to the ECtHR (see section 2.1). Schrems only referred to the CJEU's own precedents, including the seminal case of Digital Rights, where the CJEU declared the Data Retention Directive to be invalid in the light of Articles 7 and 8 of the Charter. ${ }^{96}$ It was in this latter case that the CJEU still extensively referred to the ECtHR 'by analogy' ${ }^{97}$ The absence of a reference to Strasbourg in Schrems might, firstly, reflect an idea among CJEU judges that it is not necessary to constantly refer back to Strasbourg precedents, or in the words of two interviewees to 'Adam and Eve' or 'Noah's Ark' ${ }^{98}$ It is generally considered sufficient to rely on the CJEU's own precedent in which the case law of the ECtHR was considered and quoted

\footnotetext{
92 See the reference of the Dutch court in Case C-453/16 PPU, Özçelik, ECLI:EU:C:2016:783 available at <www.minbuza.nl/binaries/content/assets/ecer/ecer/import/hof_van_justitie/nieuwe_hofzaken_inclusief_verwijzingsuitspraa k/2016/c-zakennummers/c-453-16-ppu-verwijzingsbs-rb-ams_redacted.pdf>; Case C-108/16 PPU, Dworzecki, ECLI:EU:C:2016:346, para. 16; See also C-685/15, Online Games and others, ECLI:EU:C:2017:452, para. 40.

93 AG Wathelet in Case C-231/14 P, InnoLux, ECLI:EU:C:2015:292, para. 66; AG Wahl in Case C-247/14 P, HeidelbergCement AG, ECLI:EU:C:2015:694, para. 153; AG Bot in Cases C-605/13 P and C-630/13 P, Anbouba, ECLI:EU:C:2015:1, paras. 51-55; AG Cruz Villalón in Case C-300/14, Imtech, ECLI:EU:C:2015:557, para. 42; AG Jääskinen in Case C-498/14 PPU, Bradbrooke, ECLI:EU:C:2014:2484, paras. 42 and 65; AG Sharpston in Case C-373/13, H. T., ECLI:EU:C:2014:2218, paras. 60 and 96; AG Sharpston in Case C-472/13, Shepherd, ECLI:EU:C:2014:2360, para. 51; AG Bot in Case C-614/14, Ognyanov, ECLI:EU:C:2016:111, paras. 75-91; AG Sharpston in Case C-63/13, Ghezelbash, ECLI:EU:C:2016:186, paras. 80-83; AG Bobek in Case C-640/15, Vilkas, ECLI:EU:C:2016:826, paras. 48-52 and 73; AG Sharpston in Case C-188/15, Bougnaoui, ECLI:EU:C:2016:553.

${ }^{94}$ Interviews as discussed in J KROMMENDIJK, above $\mathrm{nxx}, 827$; K LENAERTS, above $\mathrm{n} \mathrm{xx}, 875$.

${ }^{95}$ C-362/14, Schrems, ECLI:EU:C:2015:627.

${ }^{96}$ AG Bot only referred to the ECtHR when he described the main conclusions of the CJEU in Digital Rights. Case C-362/14, Schrems, ECLI:EU:C:2015:627, para. 193.

${ }^{97}$ Joined Cases C-293/12 and 594/12, Digital Rights Ireland, ECLI:EU:C:2014:238, para. 47, 54 and 55

${ }^{98}$ Interviews as discussed in J KROMMENDIJK, above $\mathrm{n} \mathrm{xx}, 829-830$.
} 
for the first time. This, for instance, happened in Åkerberg Fransson, where the CJEU referred back to Bonda in which the ECtHR's Engel-criteria determining whether a prosecution is criminal in nature played an important role. ${ }^{99}$ Schrems could also be an illustration of such a natural 'dilution' of the ECtHR case law. ${ }^{100}$ The absence of any engagement with the case law of the ECtHR might, secondly, stem from the idea that the CJEU expressed in Tele 2 as well that it is not necessary to examine this case law also because Article 8 of the Charter has no equivalent in the ECHR. ${ }^{101}$ It could also reflects an ever more confident stance of the CJEU, especially in areas dealing with fundamental rights where EU law is going ahead of ECHR developments, including data protection. ${ }^{102}$

The judgment which has maybe led to the most criticism given a failure to engage with the case law of the ECtHR is Delvigne. In this case, the Grand Chamber dealt with a reference for a preliminary ruling about French legislation which deprives persons convicted for serious crimes of their civic rights, including their right to vote. The omission of the ECHR and ECtHR is especially remarkable because AG Cruz Villalón held that this case 'brings to mind immediately the case law of the European Court of Human Rights', which he extensively discussed. ${ }^{103}$ In addition, in earlier judgments of the CJEU about voting for the elections of the European Parliament did engage with the case law of the ECtHR. ${ }^{104}$ Pertinent ECtHR judgments include Hirst and Scoppola where the ECtHR determined that a general, automatic and indiscriminate disenfranchisement of convicted prisoners breaches Article 3 of Protocol 1. ${ }^{105}$ Even though Article 39 of the Charter is not mentioned as a Charter provision that corresponds to an ECHR provision, it would have seemed appropriate for the CJEU to explicitly relate to this case law, particularly in the context of the proportionality assessment. ${ }^{106}$ This is especially true since the CJEU held that the French measure is proportionate 'in so far as it takes into account the nature and gravity of the criminal offence committed and the duration of the penalty'. ${ }^{107}$ This conclusion is noteworthy in the light of the insufficient sketch of the factual and legal French context by the referring court. AG Cruz Villalón even noted that 'there have been few occasions where the Court has been seised of a reference

\footnotetext{
${ }^{99}$ In Bonda, the Court of Justice adopted a material test in line with the ECtHR's Engel case law. Case C-617/10, Akerberg Fransson, ECLI:EU:C:2013:105, para. 35; Case C-489/10 Bonda, ECLI:EU:C:2012:319, para. 37; Engel v. Netherlands, no. 5100/71, ECLI:CE:ECHR:1976:1123JUD000510071.

${ }^{100}$ X Groussot, J HetTNE and G T Petursson, above $\mathrm{n}$ xx.

${ }^{101}$ Case C-203/15 Tele2 Sverige AB, ECLI:EU:C:2016:970, para. 129; This idea has been criticised on the grounds that there is equivalent case law of the ECtHR corresponding to Article 8. M WHITE, 'The new Opinion on Data Retention: Does it protect the right to privacy', 27 July 2016, EU Law Analysis.

102 T OJANEN, 'Making the essence of fundamental rights real: The Court of Justice of the European Union clarifies the structure of fundamental rights under the Charter. Case note on ECJ 6 October 2015, Case C-362/14, Maximilillian Schrems v Data Protection Commissioner' (2016) 2 European Constitutional Law Review 318, 329.

103 Opinion of AG Cruz Villalón in C-650/13, Delvigne, ECLI:EU:C:2015:363, para. 109.

${ }^{104}$ E.g. Case C-300/04, Eman and Sevinger, ECLI:EU:C:2006:545, paras. 36 and 54; Case C-145/04, Spain v. United Kingdom, ECLI:EU:C:2006:543, paras. 94 and 96.

${ }^{105}$ Hirst v. United Kingdom (No. 2), no. 74025/01, ECLI:CE:ECHR:2005:1006JUD007402501, para. 82; Scoppola v. Italy, no. 126/05, ECLI:CE:ECHR:2012:0522JUD000012605.

${ }^{106}$ H VAN EIJKEN and J W VAN Rossum, 'Prisoner disenfranchisement and the right to vote in election to the European Parliament: Universal suffrage key to unlocking political citzenship?' (2016) European Constitutional Law 114, 128; J SHAW, 'Prisoner voting: now a matter of EU law', 15 October 2015, EU Law Analysis.

${ }^{107}$ C-650/13, Delvigne, ECLI:EU:C:2015:648, para. 49. Contrast with AG Cruz Villalón who explicitly left the proportionality analysis for the national court. Opinion of AG Cruz Villalón in C-650/13, Delvigne, ECLI:EU:C:2015:363, paras. 123-124.
} 
for a preliminary ruling in which there is such a dearth of argument'. ${ }^{108}$ Several observers also observed that this rather lenient analysis, giving considerable leeway to the national legislature, might not have been accepted by the ECtHR because the latter conducts a more thorough proportionality assessment. ${ }^{109}$ Nonetheless, at the same time it seems not unthinkable that the CJEU was inspired by Strasbourg and the ECtHR thus had an implicit influence, since the CJEU does not explicitly refer to everything considered. ${ }^{110}$ Firstly, the CJEU for the first time recognised in line with the ECtHR that the Charter provision constitutes a right of Union citizens. This is not so evident, because at first sight Article 39(2) of the Charter does not seem to include an individual rights but merely lays down an obligation for states. ${ }^{111}$ Secondly, the CJEU's focus on the non-blanket nature of the deprivation also echoes the case law of the ECtHR. ${ }^{112}$

\subsection{No references to (the Charter of) fundamental rights}

There are also several cases in which the CJEU not only omits a reference to the EC(t)HR, but also does not engage with the Charter of fundamental rights. Even though this fifth category does not strictly speaking relate to the relationship between the CJEU and the ECtHR, it is relevant to consider. This is because this category reflects a reluctance to approach and solve cases from the perspective of fundamental rights because of the strong consciousness among CJEU judges that the Court is not a fundamental rights court. ${ }^{113} \mathrm{CJEU}$ judges consistently emphasise in lectures that: 'the Court of Justice is not a human rights court; it is the Supreme Court of the European Union'. ${ }^{114}$ Cases are preferably solved on the basis of secondary legislation, especially when that legislation contains a certain balance between clashing fundamental rights. ${ }^{115}$

In several judgments the CJEU dodged the fundamental rights related questions on procedural grounds and in doing so failed to engage to deal with the Charter on substantive grounds. ${ }^{116}$ One example is Willems which dealt with the storage and use of biometric data. The CJEU held that this falls outside

\footnotetext{
108 Opinion of AG Cruz Villalón in C-650/13, Delvigne, ECLI:EU:C:2015:363, para. 51.

${ }^{109}$ H van EuJKen and J W van Rossum, above n xx, 129-130; S CoutTs, 'Case C-650/13 Delvigne - A political citizenship?', 21 October 2015, European law blog

110 J KROMMENDIJK, above $\mathrm{nx}, 817$. CJEU Judge Lenaerts, for example held that the CJEU's research of ECtHR case law has often backed up a judgment of the CJEU but 'rarely transpires directly in the reasoning'. K LENAERTS, above $\mathrm{n} x \mathrm{x}, 873-875$; $\mathrm{G}$ DE BÚRCA, above n xx, 178.

${ }^{111}$ C-650/13, Delvigne, ECLI:EU:C:2015:648, para. 44; The ECtHR recognised this for the first time in Mathieu-Mohin and Clerfayt v. Belgium, no. 9267/81, ECLI:CE:ECHR:1987:0302JUD000926781. S Platon, 'The Delvigne judgment of the CJEU: going voldly... but perhaps not boldly enough', 24 October 2015, Verfassungsblog.

${ }^{112} \mathrm{H}$ VAN EIJKEN and J W VAN ROSSUM, above $\mathrm{n} \mathrm{xx,} \mathrm{130;} \mathrm{S} \mathrm{COUTTS,} \mathrm{above} \mathrm{n}$ xx.

113 The CJEU, for example, does not deal with the right to housing in relation to deficient Spanish mortgage law in several judgments, including Gutiérrez Naranjo, Aziz and Sánchez Morcillo. J C BENITO SÁNCHEZ, 'The CJEU and Spanish mortgage law: consumer protection, floor clauses and accelerated repayment', 20 February 2017, EU Law Analysis. Another example given during the interviews is Case C-394/12, Abdullahi, ECLI:EU:C:2013:813; Interviews as discussed in J KROMMENDIJK, above $\mathrm{nxx}, 827$.

${ }^{114}$ President Skouris during a lecture in May 2014 as quoted in L BESSELINK, 'The CJEU as the European 'Supreme Court': Setting Aside Citizens' Rights for EU Law Supremacy', 18 August 2014, Verfassungsblog.

115 E.g. Joined Cases C-680/15 and C-681/15, Asklepios Kliniken, ECLI:EU:C:2017:317, para. 27; Case C-13/16, Rīgas satiksme, ECLI:EU:C:2017:336. Interviews as discussed in J KROMMENDIJK, above $\mathrm{n} x \mathrm{x}, 827$; see also in relation to intellectual propert rights, P OLIVER AND C STOTHERS, above $\mathrm{n} \mathrm{xx}, 541$.

${ }^{116}$ For a pre-Opinion 2/13 case, see Dano, case C-333/13, ECLI:EU:C:2014:2358, paras. 89-90.
} 
the scope of Regulation No 2252/2004 on standards for security features and biometrics in passports and travel documents which means that the Charter is not applicable. The CJEU concluded this despite the fact that the referring Dutch court had explicitly stated in its referral that the Charter applied because Privacy Directive 95/46 was applicable. The CJEU did not engage with this argument and the Privacy Directive on the (rather questionable) grounds that 'by its questions, the referring court requests the interpretation of Regulation No 2252/2004 and only that regulation'. ${ }^{117}$ A similar tactic was applied by the CJEU in $X$ and $X$ about humanitarian visa and the EU Regulation establishing the Visa Code. Even though the request for such visas were 'formally submitted' on the basis of the Visa Code and the Belgian authorities had handled the requests fully in line with the Code, the CJEU considered nonetheless that the matter fell outside the scope of the Visa Code and the Charter. ${ }^{118}$ The CJEU justified this on the basis that the intention of the persons submitting applications for visas on humanitarian grounds was to apply for asylum, immediately upon their arrival in Belgium and thus 'the purpose of the application differs from that of a short-term visa'. ${ }^{119}$ The reliance on intentions rather than formal connections has been criticised. ${ }^{120}$

Several other post-Opinion 2/13 judgments illustrate the tendency to downplay fundamental rights as well. One interesting area where this is visible are cases dealing with the right to an effective remedy and the principle of effective judicial protection. ${ }^{121}$ In such cases, the CJEU has also, albeit not consistently ${ }^{122}$, refrained from referring to or analysing the issue in the light of Article 47 of the Charter and Article 6 ECHR and the case law of the ECtHR. ${ }^{123}$ In Orizzonte, the CJEU, for example, ruled on an Italian court fees scheme which provides for fees which are higher in procurement cases than in ordinary administrative cases. ${ }^{124}$ In addition, this system also enables courts to raise new (cumulative) fees for supplementary pleas which broaden the dispute. The CJEU examined this scheme in the context of the procedural autonomy of Member States and the limitations under the principle of effectiveness and equivalence. By contrast, AG Jääskinen approached the matter from the point of view Article 47 of the Charter and also discussed a pertinent judgment of the ECtHR in relation to court fees as an obstacle

\footnotetext{
117 Case C-446/12, Willems, ECLI:EU:C:2015:238, para. 52.

${ }^{118}$ AG Mengozzi in Case C-638/16 PPU, $X$ and $X$, ECLI:EU:C:2017:93, paras. 32-33 and 47.

${ }^{119}$ C-638/16 PPU, $X$ and $X$, ECLI:EU:C:2017:173, para. 47.

${ }^{120}$ For a more extensive discussion of this (in Dutch), see J KrommEnduK, case note on C-638/16 PPU, $X$ and $X$, European Human Rights Cases 2017/81; M OvÁDEK, 'The CJEU on humanitarian via: discovering 'un-chartered' waters of EU law', 13 March 2017, Verfassungsblog.

${ }^{121}$ Case C-63/15, Ghezelbash, ECLI:EU:C:2016:409; Case C-155/15, Karim, ECLI:EU:C:2016:410. M den Heijer, 'Remedies in the Dublin Regulation: Ghezelbash and Karim' (2017) Common Market Law Review 859, 866.

${ }^{122}$ See recently Case C-205/15, Toma, ECLI:EU:C:2016:499, paras. 41-44 and 55-56. J KROMMENDIJK, case note on Case C205/15, Toma, European Human Rights Cases 2016/203.

${ }^{123}$ Safjan counted that only 16 out of the approximately 60 post-Lisbon cases dealing with effective judicial protection referred to Strasbourg case law, something which Prechal qualified as understandable because Article 47 of the Charter is a self-standing principle. M SAFJAN, 'A Union of effective judicial protection. Addressing a multi-level challenge through the lens of Article 47 CFREU', King's College London, <www.kcl.ac.uk/law/research/centres/european/Speech-KINGS-COLLEGE.pdf〉, p. 9. 124 Case C-61/14, Orizzonte Salute, ECLI:EU:C:2015:655. J KROMMENDIJK, 'Is there light on the horizon? The distinction between 'Rewe-effectiveness' and the principle of effective judicial protection in Article 47 of the Charter after Orizzonte' (2016) Common Market Law Review 1395.
} 
to the right of access to a court. ${ }^{125}$ Something similar happened in Târşia. This case dealt with the impossibility for Romanian courts to revise a final decision of a court in civil proceedings when that decision is subsequently found to be incompatible with an interpretation of EU law, while that possibility exists in relation to administrative proceedings. The Grand Chamber again approached the matter from the angle of procedural autonomy excluding any discussion of the EC(t)HR and Charter while only referring in more general terms to the rights of the defence and the principle of legal certainty. ${ }^{126}$ The latter is especially remarkable in this case where the referring court explicitly asked about the conformity of the Romanian rule with several Charter provisions, including Article 47. AG Jääskinen, nonetheless, discussed rather extensively the case law of the ECtHR. ${ }^{127}$ Likewise, in Chmieleski, AG Wathelet discussed three judgments of the ECtHR on the proportionality of sanctions extensively, while the CJEU remained silent on these and did not even refer to the Article 49(3) of the Charter. ${ }^{128}$

The limited scrutiny of fundamental rights is also visible in family reunification immigration cases. ${ }^{129}$ One example is $P$ and $S$. In this judgment, the CJEU was critical of the relatively high amount of Dutch fines for third-country nationals who are long-term residents and who fail the civic integration examination. The CJEU held that such high fines are liable to jeopardise the achievement of the objectives pursued by Directive 2003/109 without reflecting on the case law of the ECtHR with respect to the proportionality of penalties as the AG did. ${ }^{130}$ Another example is $K$ and $A$ dealing with the requirement for third country nationals to pass a civic integration assessment. ${ }^{131}$

\section{Concluding remarks: Opinion 2/13 as a game changer?}

It goes beyond the scope of this chapter to reflect on the diverse approach of the CJEU from a more normative point of view. Suffice to say that an alleingang is not wholly inappropriate when the EU law provides a higher level of fundamental rights protection than the ECHR or the case law of the ECtHR, as in Delvigne and Genc. ${ }^{132}$ What is, however, most problematic is the diverse and conflicting approach, especially for national courts who struggle to reconcile EU law with the ECHR and the case law of the

\footnotetext{
${ }^{125}$ Stankov v. Bulgaria, no. 68490/01, ECLI:CE:ECHR:2007:0712JUD006849001para 52. AG Jääskinen in Case C-61/14, Orizzonte Salute, ECLI:EU:C:2015:307, para. 38.

${ }^{126}$ Case C-69/14, Târșia, ECLI:EU:C:2015:662, para. 38.

${ }^{127}$ AG Jääskinen in Case C-69/14, Târșia, ECLI:EU:C:2015:396, paras. 40-43.

${ }^{128}$ Case C-255/14, Chmielewski, ECLI:EU:C:2015:475; AG Wathelet in Case C-255/14, Chmielewski, ECLI:EU:C:2015:308, paras. 36-64. Other cases in which the CJEU only relies on general principles of EU law instead of the Charter include Case 59/11, Kokopelli, ECLI:EU:C:2012:447; Case C-206/13, Siragusa, ECLI:EU:C:2014:126, para. 34; Joined Cases C-29/13 and C-30/13, Global Trans Lodzhistik, ECLI:EU:C:2014:140, para 51. X Groussot, J HeTtne and G T Petursson, above n xx.

${ }^{129}$ Contrast the more recent judgments with older judgments couched in terms of fundamental rights, such as Case C-109/01, Akrich, ECLI:EU:C:2003:491, para. 60; Case C-60/00, Carpenter, ECLI:EU:C:2002:434, para. 42. M DE SOMER and M P VINK, 'Precedent' and fundamental rights in the CJEU's case law on family reunification immigration', in: C NEUHOLD and S VANHOONACKER (eds): 'Dynamics of institutional cooperation in the European Union: Dimensions and effects' (2015) European Integration online Papers 1.

${ }^{130}$ C-579/13, $P$ and $S$, ECLI:EU:C:2015:39, para. 104.

${ }^{131}$ AG Kokott did refer, albeit in a footnote, to the case law of the ECtHR in order to support the interpretation that married couples do not have an unconditional right to residence in a particular state. Case C-153/14, K and A, ECLI:EU:C:2015:186, para. 31.

${ }^{132}$ See also Case C-528/15, Al Chodor, ECLI:EU:C:2017:213.
} 
ECtHR, as is also illustrated by the request for a preliminary ruling by the Dutch court in J.N.. ${ }^{133}$ The typology in the previous section illustrates the diversity in the way in which the CJEU has dealt with the case law of the ECtHR. There is especially a discrepancy between, on the one hand, the more "Strasbourg-friendly" judgments of Aranyosi, C.K. and WebMindLicenses and, on the other hand, J.N., Achbita and Delvigne. These differences are nothing new and reflect earlier observations of academics and CJEU judges and référendaires that there is no uniform practice or methodology with respect to the case law of the ECtHR. ${ }^{134}$ It is not always clear how the differences in the approach of the CJEU could be explained and what the reasons behind a (non) citation are. It is not the purpose of this chapter to explain those differences. It is sufficient to say that some of these differences can be attributed to the composition of a Chamber and the involved judges and référendaires with different writing styles, legal background and areas of expertise. ${ }^{135}$ In addition, the CJEU is also more compelled to refer to the ECtHR when the (intervening) parties relied on it or when the national court explicitly asked about it. ${ }^{136}$ This is, however, not necessarily always the case. ${ }^{137}$

The previous sections beg the question as to whether there has been a change in the way in which the CJEU has dealt with the case law of the ECtHR since Opinion 2/13. Section 1 showed that the CJEU has become more reluctant from a formal point of view to attach legal value to the ECtHR since Opinion 2/13. This, has, however not necessarily resulted in a neglect of Strasbourg case law as section 2 illustrated. Nor has it led to CJEU judgments that contradict the position of the ECtHR, also because CJEU judges and référendaires are (still) concerned with preventing an open conflict with the ECtHR. ${ }^{138}$ The current President of the CJEU, Lenaerts, recently referred to the ECtHR as 'a valuable ally' from which the CJEU draws inspiration leading to a 'constructive dialogue' and 'crossfertilization'. ${ }^{139}$

It is not surprising that Opinion $2 / 13$ is not a game changer, because it is logical that the CJEU, after having given such a heavy blow towards the ECHR system in its Opinion, exercises some caution and damage control by giving the impression that it is not hostile towards the ECtHR. This could especially be said about Aranyosi and C.K. where the CJEU departed from Opinion 2/13 and reconciled

\footnotetext{
${ }^{133}$ Above $\mathrm{n}$ x.

${ }^{134} \mathrm{~J}$ KROMMENDIJK, above $\mathrm{nxx}, 817$; Douglas-Scott, for example, labeled the practice as 'messy, unpredictable and complex', while De Búrca pointed to the 'increasingly selective' use of the Strasbourg case law and the 'detached, autonomous and potentially uninformed case law' of the Court of Justice with respect to fundamental rights. S DougLAS-SCOTT, above $\mathrm{n} \mathrm{xx}$, 657-658 and 665; G. DE BÚRCA, above n xx, 173-174. De Witte likewise referred to the 'eclectic and unsystematic' approach. B DE WITTE, above $\mathrm{n} x \mathrm{x}, \mathrm{p} .19$.

135 J KROMMENDIJK, above $\mathrm{n} \mathrm{xx}, 825$.

${ }^{136}$ E.g. Case C-398/13 P, Inuit Tapiriit Kanatami, ECLI:EU:C:2015:535.

137 E.g. C-615/13 P, Client Earth, ECLI:EU:C:2015:489, para. 29. In another case the Council relied on the case law of the ECtHR with respect to the immunity of international organisations. Opinion of AG Bot in C-146/13, Spain v. Parliament and Council, ECLI:EU:C:2014:2380, para. 33 and C-146/13, Spain v. Parliament and Council, ECLI:EU:C:2015:298. See also Opinion of AG Wahl in C-194/14 P, AC-Treuhand, ECLI:EU:C:2015:350, para. 16; C-201/14, Bara and others, ECLI:EU:C:2015:638, para. 46.

${ }^{138}$ Interviews as discussed in J KrommendiJK, above $\mathrm{n} \mathrm{xx,} \mathrm{820;} \mathrm{S} \mathrm{MoRANO-FoAdi} \mathrm{and} \mathrm{S} \mathrm{ANDREADAKIS,} \mathrm{'A} \mathrm{report} \mathrm{on} \mathrm{the}$ protection of fundamental rights in Europe: a reflection on the relationship between the Court of Justice of the European Union and the European Court of Human Rights' (2014), <dm.coe.int/CED20140017597>, 43 and 47-48.

${ }^{139}$ K LENAERTS, above n xx, p. 839-840.
} 
the principle of mutual trust with fundamental rights fully in line with the case law of the ECtHR. Nonetheless, the CJEU relies increasingly on the Charter and its own case law. Almost all interviewees and academics noted the tendency at the CJEU to refer less often to the ECHR and the case law of the ECtHR after the entry into force of the Charter. This is a trend that already started before Opinion 2/13 and reflects the earlier mentioned Charter-centrism idea of the EU now having its 'own catalogue' of fundamental rights. ${ }^{140}$ Likewise, another trend which seems to have started already before Opinion 2/13, but which might have become more prominent after Opinion 2/13, is that Strasbourg is cited with less "fanfare" and in a more modest way without elevating the ECtHR to the level of being a prominent source of rights. The CJEU has, for example, refrained from referring to the case law of the ECtHR as 'a source of inspiration' or of being of 'special significance'. ${ }^{141}$ Nor has it referred to the judgments of the ECtHR 'by analogy'. ${ }^{142}$ Neither have judgments of the ECtHR been directly relied upon as if it they are similar to the CJEU's own judgments. ${ }^{143}$ The more humble role of the EC(t)HR also reflects the 'hierarchy' in Article 6 TEU, which refers to the Charter in the first paragraph, while the supplementary role of the ECHR as general principles of EU law is listed in the third paragraph. ${ }^{144}$

The Charter-centrism will most likely continue, since the redrafting of the agreement on the accession of the EU to the ECHR will undeniably take a long time. ${ }^{145}$ It is increasingly questioned whether accession will ever happen, even though the President of the European Commission Juncker held in April 2016 that accession is a political priority for the Commission. He added: 'It is also a personal commitment. We are working on a solution to that accession and we will not rest until we have found a solution'. ${ }^{146}$ This was, however, before Brexit, which has undeniably moved accession lower on the political agenda. ${ }^{147}$ The Council of Europe Steering Committee for Human Rights, for example, held in December 2015 'At this time, it remains to be seen when, how and if accession will be completed' (empashsis added). ${ }^{148}$ The long time needed for negotiation and ratification will in any case be amply used by the Court of Justice to develop and bolster its own fundamental rights case law. This is also because the existence of the preliminary reference procedure also puts the ECtHR at a disadvantage since it enables all national courts to receive guidance on fundamental rights within less than 15 months when those courts ask questions about Charter. ${ }^{149}$ By contrast, without the entry into force of Protocol

\footnotetext{
${ }^{140}$ Interviews as discussed in J KROMMENDIJK, above n xx, 832; Opinion 2/13, para. 170.

141 E.g. C-540/03, Parliament v. Council, ECLI:EU:C:2006:429, para. 35; Case C-112/00, Schmidberger, ECLI:EU:C:2003:333, para. 71; Case C-283/05, ASML, ECLI:EU:C:2006:787, para. 26; Opinion of Advocate General Bot in Case C-43/12 Commission v. Parliament and Council, ECLI:EU:C:2014:298, para. 65.

142 E.g. Joined Cases C-293/12 and 594/12, Digital Rights Ireland, ECLI:EU:C:2014:238, para. 47,54 and 55.

${ }^{143}$ E.g. Joined Cases C-92/09 and 93/09 Volker und Markus Schecke and Eifert, ECLI:EU:C:2010:662, para. 52. One (recent) exception, however, is one of the many references to the ECtHR in WebMindLicenses where the CJEU refers to the ECtHR while only mentioning the relevant Charter provision but without the relevant ECHR article. Case C-419/14, WebMindLicenses Kft., ECLI:EU:C:2015:832, para. 81.

$144 \mathrm{~J}$ KROMMENDIJK, above $\mathrm{n}$ xx, 834.

$145 \mathrm{~J}$ KROMMENDIJK, above $\mathrm{n}$ xx, 835.

146 Assembly of the Council of Europe, ordinary session, 19 April 2016, AA16CR12.

147 The Commission's Work Programme of October 2017, nonetheless, stated that the Commission 'will continue to work towards accession'. COM(2016) 710 final

148 SteERING COMMITTEE FOR HuMAN Rights, above n xx, para. 177.

${ }^{149}$ CJEU, above n xx, p. 2.
} 
16 to the ECHR, (the highest) nationals courts cannot turn to the ECtHR for Advisory Opinions and have to handle interpretational questions on their own. Because of the growing number of questions on the Charter the CJEU will (in some cases) be forced to behave like a human rights court even if the CJEU does not consider itself to be such a court. ${ }^{150}$ The recent EAW judgment of the Bundesverfassungsgericht is a timely warning for the CJEU that it should not forget its tasks in relation to fundamental rights. ${ }^{151}$ The CJEU's own self-image or reluctance to see itself as a fundamental rights court thus does not entirely reflect its actual practice. As a matter of fact, the CJEU has increasingly shown that it is not shying away from acting as the guardian of EU fundamental rights by issuing bold judgments in some areas of law, including data protection and privacy (Digital Rights Ireland, Google Spain and Schrems) or asylum (N.S. and CK).

The growing Charter jurisprudence of the CJEU might consequently diminish the felt need to accede to the ECHR even more. In addition, it is not unthinkable that some EU Member States will become more wary of redrafting the accession agreement in such a way that it complies with all "demands" of the CJEU as laid down in Opinion 2/13. This is a monstrous exercise that would basically mean that the principle of equality of contracting parties under the ECHR should be dropped in order to preserve the specific characteristics and autonomy of EU law. ${ }^{152}$ This would grant the EU a more favourable position under the ECHR than the other States Parties, which would undoubtedly result in similar requests from other States Parties to the ECHR or be used as justification for their noncompliance with the ECHR or judgments of the ECtHR. This would thus erode the ECHR regime. It remains to be seen whether EU Member States truly want to go down that bumpy road and whether they consider that the gains of an EU accession to the ECHR outweigh these risks involved. This is even more so, because the ECtHR is in practice already dealing with many EU law issues. ${ }^{153}$

In sum, Opinion $2 / 13$ has to date not really been a game changer, but this might be different in several years' time when looking back in hindsight.

\footnotetext{
${ }^{150}$ See also AG Bot in Cases C-404/15 and C-659/15 PPU, Pál Aranyosi (C-404/15) and Robert Căldăraru (C-659/15 PPU), ECLI:EU:C:2016:140, para. 175; D SARMIENTO, 'The German Constitutional Court and the European Arrest Warrant: The latest twist in the judicial dialogue', 27 January 2016, EU Law Analysis.

${ }^{151}$ Order of 15 December 2015, 2 BvR 2735.14; D SARMIENTO, above n xx.

152 CJEU judge Malinovský considered the accession agreement full of improvisation work without any precedent in international law. J MALINOvskÝ, 'L'adhésion de l'U.E. a la Convention européenne des Droits de l'Homme' (2015) Revue générale de droit international public 705, 739. J POLAKIEWICZ, 'Europe's multi-layered human rights protection system: Challenges, opportunities and risks', 13 March 2016, EU Law Analysis. X Groussot, J HetTnE and G T Petursson, above n $\mathrm{xx}$.

${ }^{153} \mathrm{~J}$ POLAKIEWICZ, above $\mathrm{n} \mathrm{xx}$; L GLAS and J KROMMENDIJK, above $\mathrm{n}$ xx.
} 